\title{
Model Integrasi Penjadwalan Produksi Batch dan Penjadwalan Perawatan dengan Kendala Due Date
}

\author{
${\text { Zahedi }{ }^{*} \text {, TMA Ari Samadhi², Suprayogi², Abdul Hakim Halim² }}^{2}$
}

\begin{abstract}
This paper discusses the integration model of batch production and preventive maintenance scheduling on a single machine producing, an item to be delivered at a common due date. The machine is a deteriorating machine that requires preventive maintenance to ensure the availability of the machine at a desired service level. Decision variables of the model are the number of preventive maintenances, the schedule, length of production runs, as well as the number of batches, batch sizes and the production schedule of the resulting batches for each production run. The objective function of the model is to minimize the total cost consisting of inventory costs during parts processing, setup cost and cost of preventive maintenance. The results show three important points: First, the sequence of optimal batches always follows the SPT (short processing time). Second, variation of preventive maintenance unit cost does not influence the sequence of batches. Third, the first production run length from production starting time is smaller than the next production run length and this pattern continues until the due date. When in process inventory unit cost is increased, the pattern will continue until a specified cost limit, and beyond the limit the pattern will change to be the opposite pattern.
\end{abstract}

Keywords: Batch scheduling, deteriorating machine, service level, preventive maintenance.

\section{Pendahuluan}

Penjadwalan produksi yang tidak mempertimbangkan aspek perawatan akan menyebabkan sebuah mesin yang seharusnya menjalani perawatan tetap digunakan. Apabila perawatan tidak dilakukan bisa berakibat mesin mengalami break down. Hal ini akan mengganggu kegiatan produksi. Di pihak lain, jadwal perawatan yang tidak mempertimbangkan jadwal produksi akan menyebabkan sebuah mesin yang sedang sibuk harus dihentikan karena harus menjalani perawatan. Hal ini juga mengganggu jadwal produksi yang telah disusun sebelumnya.

Gambaran nyata dapat dijelaskan pada kasus berikut. Perusahaan X mendapatkan order pekerjaan pemesinan (machinery work) dari industri-industri rekanan dalam kuantitas yang besar untuk setiap order. Perusahaan X mengerjakan pekerjaan dalam batch dengan ukuran batch konstan yang ditetapkan oleh bagian produksi. Sementara itu, bagian perawatan melakukan perbaikan mesin hanya apabila terjadi kerusakan pada mesin (reactive maintenance). Keterlambatan penyerahan pesanan kepada konsumen tidak bisa dihindarkan jika pada saat mesin

\footnotetext{
${ }^{1}$ Sekolah Ilmu Komputer, Jurusan Matematika, Universitas Bina Nusantara, J. K. H. Syahdan 9, Palmerah, Jakarta Barat 11480. Indonesia. Email: zahedizahedi@binus.ac.id

2 Fakultas Teknologi Industri, Program Studi Teknik Industri, Institut Teknologi Bandung, Jl. Ganesha 10, Bandung 40132, Indonesia. Email: asamadhi@mail.ti.itb.ac.id, yogi@mail.ti.itb.ac.id, ahakimhalim@lspitb.org

* Penulis korespondensi
}

sedang melakukan kegiatan produksi, mesin harus menjalani perbaikan yang lama karena rusak. Hal seperti ini sering terjadi.

Dari uraian di atas dapat ditarik beberapa akar masalah yang dihadapi, yaitu, pertama, bagian perawatan belum menerapkan sistem perawatan preventif, meskipun data waktu kerusakan mesin, selang waktu antar kerusakan dan biaya setiap kerusakan sudah tercatat dengan baik. Kedua, bagian produksi menjadwal batch dalam ukuran yang konstan, padahal menurut Dobson et al. [1, 2] dan Halim dan Ohta [3, 4], ukuran batch yang tidak konstan akan memberikan flow time yang lebih baik. Ketiga, data menunjukkan bahwa kerusakan mesin terjadi pada saat produksi sedang berlangsung, sehingga kerusakan mesin mengganggu produktivitas lantai pabrik.

Penelitian-penelitian yang membahas integrasi penjadwalan batch dan penjadwalan perawatan dengan asumsi waktu perawatan deterministik, antara lain dilakukan oleh Abboud et al. [5], Yeh et al. [6], Kim et al. [7], Herbon et al. [8], Iravani dan Deunyas [8], Indrapriatna [10] serta Altendorfer et al. [11]. Kesamaan masalah yang dibahas adalah penentuan jadwal produksi dan ukuran batch optimal dengan jadwal perawatan mesin telah diketahui sebelumnya.

Penelitian-penelitian yang mengintegrasikan penjadwalan batch satu mesin dan penjadwalan perawatan dengan asumsi waktu perawatan probabi- 
listik yang ditentukan dengan metode optimisasi di antaranya adalah Lee dan Rosenblat [12], Wang dan Sheu [13], Tseng [14], Ben-Daya dan Noman [15], Lin dan Hou [16], Chelbi et al. [16], Makhdoum [18], El-Ferik dan Ben-Daya [19], Fitouhi dan Nourelfath, [20] serta Suliman dan Jawad [21]. Penelitian-penelitian ini sama-sama membahas integrasi penjadwalan batch dan penjadwalan perawatan pada satu mesin terdeteriorasi, single item, tipe produk diskrit, dan keputusan jumlah dan ukuran batch serta waktu perawatan optimal ditentukan oleh trade off dari setup cost, quality cost, restoring cost, holding cost dan rework cost. Dalam model Wang dan Sheu [13], Tseng [14], Ben-Daya dan Noman [15], Lin dan Hou [16] ditambahkan warranty cost. Lee dan Rosenblat [12] menggunakan kebijakan perawatan inspeksi, Wang dan Sheu [13] menggunakan kebijakan perawatan disregard the first-s (DTF-s) dan corrective maintenance (CM). Sementara Ben-Daya dan Noman [15] menggunakan kebijakan perawatan imperfect preventive maintenance (PM) dan $\mathrm{CM}$, Lin dan Hou [16] menggunakan kebijakan perawatan PM dan CM, Chelbi et al. [16] menggunakan kebijakan age-based PM serta El-Ferik dan BenDaya [19] menggunakan kebijakan perawatan PM pada akhir setiap production run atau jika suatu keruakan terjadi, tetapi Makhdoum [18] dan Tseng [14] hanya menggunakan kebijakan perawatan PM. Selanjutnya Fitouhi dan Nourelfath [20] menggunakan kebijakan perawatan PM replacement dan CM serta Suliman dan Jawad [21] memperbaiki hasil yang diperoleh oleh Chelbi et al. [16] dengan mengusulkan kebijakan perawatan kombinasi antara inspeksi dan age-based PM. Penelitian-penelitian ini tidak melibatkan due date dalam pembahasannya.

Berdasarkan uraian di atas, maka dapat dilihat bahwa perlu dilakukan pengintegrasian penjadwalan batch dan penjadwalan perawatan preventif (preventive maintenance/PM). Artinya, jadwal produksi dan jadwal preventif ditentukan secara bersamaan. Penelitian ini mengusulkan model integrasi penjadwalan batch dan penjadwalan perawatan pada sistem manufaktur satu mesin yang memproduksi sejumlah part sejenis yang harus dikirim secara bersamaan pada saat due date tertentu (common due date). Variabel keputusan model adalah jumlah dan jadwal perawatan preventif (preventive maintenance/PM), panjang interval antar dua PM yang berurutan (production run) serta jumlah batch, ukuran batch dan jadwal batch produksi pada setiap production run. Fungsi tujuan adalah meminimisasi total biaya, yang terdiri dari biaya simpan selama part diproses, biaya setup dan biaya PM. Penelitian ini mengasumsikan tidak ada part non conforming selama berproduksi.

\section{Metode Penelitian}

\section{Pengembangan Model}

Untuk pengembangan model integrasi penjadwalan batch dan penjadwalan perawatan pada sistem manufaktur satu item satu mesin, didefinisikan parameter-parameter model dan variabel-variabel model seperti di bawah ini.

Parameter-parameter model

$q \quad$ : jumlah part dari satu item sejenis yang akan diproses pada satu mesin

$d$ : waktu penyerahan seluruh part (common due date)

$t \quad: \quad$ waktu proses per part

$s \quad$ : waktu setup antar batch

c1 : biaya simpan untuk finished-part per unit per satuan waktu (satuan biaya)

c2 : biaya simpan untuk work-in-process part per unit per satuan waktu (satuan biaya)

$c_{s} \quad$ : biaya untuk satu kali setup (satuan biaya)

cPM: biaya untuk satu kali PM (satuan biaya)

$t P M$ : panjang interval waktu PM

$\beta$ : parameter bentuk dari distribusi Weibull

$\alpha$ : parameter skala dari distribusi Weibull

$\mu \quad$ : laju perbaikan mesin (konstan)

$A$ : ketersediaan mesin

Variabel-variabel model:

$L_{\left[i_{k} k\right]} \quad$ : batch yang dijadwalkan pada posisi ke-i dalam production run ke- $k$ (secara backward), $i k=1,2, \ldots, N k, k=1,2, \ldots, g$

$Q_{\left[i_{k} k\right]} \quad:$ ukuran batch $L_{\left[i_{k} k\right]}$ dalam unit

$N$ : jumlah batch maksimum untuk g production run

Nk : jumlah batch maksimum dalam production run ke-k, $k=1,2, \ldots, g$

$B_{\left[i_{k} k\right]} \quad:$ saat mulai pemrosesan batch $L_{\left[i_{k} k\right]}$

$C_{\left[i_{k} k\right]} \quad$ : saat selesai batch $L_{\left[i_{k} k\right]}$

$P M[k]$ : preventive maintenance ke- $k, k=1,2, \ldots, g$

$B P M[k]$ : saat mulai PM ke- $k, k=1,2, \ldots, g$

$C P M[k]$ : saat selesai PM ke- $k, k=1,2, \ldots, g$

$G \quad$ : jumlah production run

ToIC $[k]$ : total biaya simpan part untuk $k$ production run, $k=1,2, \ldots, g$

TCPM : total biaya PM

TCS : total biaya setup

$T C \quad$ : total biaya

$T C_{\left[i_{k} k\right]}$ : total biaya pada iterasi ke-ik, $k$ dalam algoritma

$T C^{*} \quad$ : total biaya terbaik dalam algoritma

$L R[k]$ : panjang production run ke- $k, k=1,2, \ldots$, $g$, dihitung dari awal production run termasuk setup sampai berakhirnya production run tersebut pada solusi terbaik algoritma

$N R[k]$ : jumlah batch dalam production run ke- $k$, $k=1,2, \ldots, g$, pada solusi terbaik algoritma 


$$
\begin{aligned}
X_{\left[i_{k} k\right]}= & \left\{\begin{array}{l}
1, \text { jika } Q_{\left[i_{k} k\right]} \neq 0, \\
0, \text { jika } Q_{\left[i_{k} k\right]}=0 .
\end{array}, i k=1,2, \ldots, N k, k=1,\right. \\
& 2, \ldots, g
\end{aligned}
$$

Biaya simpan dalam Indrapriatna et al. [10] dikembangkan dari Halim dan Ohta [4] dapat dijelaskan sebagai berikut. Misalkan terdapat $q$ part dari satu jenis item akan dijadwal dengan kriteria minimisasi waktu tinggal aktual (actual flow time) dan akan diserahkan pada suatu due date bersama $d$, sebagaimana ditunjukkan pada Gambar 1.

Misalkan $q$ part tersebut dibagi menjadi $N$ batch $L[i]$ $(i=1,2, \ldots, N)$ dengan ukuran masing-masing batch adalah $Q[i] \quad(i=1,2, \ldots, N)$. Diasumsikan bahwa bahan baku datang tepat pada saat dibutuhkan, yaitu pada saat awal pemrosesan batch, maka biaya simpan hanya untuk in-process-batch (batch yang masih mengandung part yang belum atau sedang diproses) dan completed-batch (seluruh part dalam batch sudah selesai diproses). Asumsi untuk inprocess-batch adalah bahwa part di dalam suatu batch akan menunggu dalam batch tersebut sampai seluruh part dalam batch tersebut selesai diproses. Indrapriatna et al. [10] merumuskan total biaya simpan part untuk satu production run adalah sebagaimana ditunjukkan pada Persamaan (1).

$$
\begin{aligned}
\operatorname{ToIC}[1]= & c 1 \sum_{i=1}^{N-1}\left\{\sum_{j=1}^{i}\left(t Q_{[j]}+s\right)\right\} Q_{i+1}+ \\
& \frac{c_{1}+c_{2}}{2} t \sum_{i=1}^{N} Q_{[i]}^{2}+\frac{c_{2}-c_{1}}{2} t \sum_{i=1}^{N} Q_{[i]}
\end{aligned}
$$

Suku pertama dalam Persamaan (1) adalah total biaya simpan untuk semua batch selesai (completed batch) dan suku kedua dan ketiga adalah total biaya simpan selama part diproses dalam batch (in process batch) dalam satu production run.

Model konseptual dari penjadwalan batch dengan $g$ production run akan memiliki susunan batch sebagaimana ditunjukkan pada Gambar 2.

Pengembangan biaya simpan untuk $g$ production run yang dikembangkan dari Indrapryatna et al. [10] adalah sebagaimana ditunjukkan pada Persamaan (2).

$$
\begin{aligned}
T o I C[g]= & c 1 \sum_{i=1}^{N-1}\left\{\sum_{j=1}^{i}\left(t Q_{\left[j_{1} 1\right]}+s\right)\right\} Q_{\left[(i+1)_{1} 1\right]}+ \\
& \frac{c_{1}+c_{2}}{2} t \sum_{i_{1}=1}^{N_{1}} Q_{\left[i_{1} 1\right]}^{2}+\frac{c_{2}-c_{1}}{2} t \sum_{i_{1}=1}^{N_{1}} Q_{\left[i_{1} 1\right]} \\
& +\sum_{k=2}^{g}\left[c 1 \sum_{i_{k}=1}^{N_{k}-1}\left\{\sum_{j=1}^{i}\left(t Q_{\left[j_{k} k\right]} S\right)\right\} Q_{\left[(i+1)_{k} k\right]}+\right. \\
& \frac{c_{1}+c_{2}}{2} t \sum_{i_{k}=1}^{N_{k}} Q_{\left[i_{k} k\right]}^{2}+\frac{c_{2}-c_{1}}{2} t \sum_{i_{k}=1}^{N_{k}} Q_{\left[i_{k} k\right]}^{2} \\
& \left.+c_{1} \sum_{i_{k}=1}^{N_{k}} Q_{\left[i_{k} k\right]}\left((k-1) t_{P M}+\sum_{j_{k}=1}^{N_{(k-1)}}\left(t Q_{\left[j_{k} k\right]}+s\right)\right)\right](2)
\end{aligned}
$$

Untuk menentukan waktu maksimum antar dua PM digunakan proposisi dari Duarte dan Soares [22] sebagaimana Proposisi 1.

\section{Proposisi 1. (Duarte dan Soares [22])}

Misal suatu sistem memenuhi karakteristik Weibull dengan increasing hazard rate $h(t)=\frac{\beta t^{\beta-1}}{\alpha^{\beta}}, \beta>1, a$ $>0, t>0$ dan constant repair rate $\mu$. Untuk menjamin ketersediaan sistem sama atau lebih besar dari $A$, maka panjang interval antar dua PM berurutan haruslah sama atau lebih kecil dari $\sqrt[\beta-1]{\frac{\mu(1-A)}{A} \alpha^{\beta}}$.

Duarte dan Soares [22] mensyaratkan PM dalam Proposisi 1 tersebut adalah perfect maintenance sehingga setelah PM dilaksanakan maka mesin menjadi as good as new. Dalam suatu planning horizon dengan $g$ production run akan terdapat $g$ PM. Setiap PM adalah perfect maintenance. PM pertama terjadwal atau PM terakhir yang dilakukan tepat saat due date $d$, untuk menjamin pada saat planning horizon berikutnya mesin dalam kondisi as good as new. Total biaya PM dinyatakan dengan

$T C P M=g c P M$

Misalkan setiap production run memiliki $N_{k}$ batch, $k$ $=1,2, \ldots, g$, maka total biaya setup adalah;

$T C S=c_{S} \sum_{k=1}^{g} N_{k}$

Dengan demikian total biaya terdiri dari biaya simpan, biaya PM dan biaya setup, dapat dinyatakan dengan;

$T C=T o I C[g]+T C P M+T C S$

Model integrasi penjadwalan batch dan penjadwalan perawatan preventif dapat dirumuskan sebagaimana Model [SISS].

\section{Model [SISS]}

Minimisasi $T C=$ $c 1 \sum_{i=1}^{N-1}\left\{\sum_{j=1}^{i}\left(t Q_{\left[j_{1} 1\right]}+s\right)\right\} Q_{\left[(i+1)_{1} 1\right]}+$ $\frac{c_{1}+c_{2}}{2} t \sum_{i_{1}=1}^{N_{1}} Q_{\left[i_{1} 1\right]}^{2}+\frac{c_{2}-c_{1}}{2} t$ $+\sum_{k=2}^{g}\left[c 1 \sum_{i_{k}=1}^{N_{k}-1}\left\{\sum_{j=1}^{i}\left(t Q_{\left[j_{k} k\right]}+s\right)\right\} Q_{\left[(i+1)_{k} k\right]}+\right.$ $\frac{c_{1}+c_{2}}{2} t \sum_{i_{k}=1}^{N_{k}} Q_{\left[i_{k} k\right]}^{2}+\frac{c_{2}-c_{1}}{2} t \sum_{i_{k}=1}^{N_{k}} Q_{\left[i_{k} k\right]}+$ $\left.c_{1} \sum_{i_{k}=1}^{N_{k}} Q_{\left[i_{k} k\right]}\left((k-1) t_{P M}+\sum_{j_{k}=1}^{N_{(k-1)}}\left(t Q_{\left[j_{k} k\right]}+s\right)\right)\right]$

$+g c P M+c_{s} \sum_{k=1}^{g} N_{k}$

Kendala

$\sum_{k=1}^{g} \sum_{i_{k}=1}^{N_{k}} Q_{\left[i_{k} k\right]}=q$

$B_{\left[i_{1} 1\right]}+\sum_{j_{1}=1}^{i_{1}}\left(s X_{\left[j_{1} 1\right]}+t Q_{[i 1]}\right)-s=d$,

$i_{1}=1, \ldots, N_{1}, k=1$ 


\begin{tabular}{|c|c|c|c|c|c|c|c|c|c|}
\hline & & & & & & & $\begin{array}{l}\text { batch dalam } \\
\text { proses untuk } \\
\text { batch } L_{[2]}\end{array}$ & & $\begin{array}{l}\text { batch selesai } \\
\text { untuk batch } L_{[2]}\end{array}$ \\
\hline & & & & & & & $t Q_{[2]}$ & $S$ & $t Q_{[1]}$ \\
\hline$s$ & $L_{[N]}$ & $\cdots$ & $s$ & $L_{[i]}$ & $\cdots$ & $s$ & $L_{[2]}$ & $s$ & $L_{[1]}$ \\
\hline & $B_{[M]}$ & & & $B_{[i]}$ & & & $B_{[2]}$ & & $B_{[1]}$ \\
\hline
\end{tabular}

Gambar 1. Posisi batch dalam sistem manufaktur satu mesin dalam satu production run (Indrapriatna et al. [10])

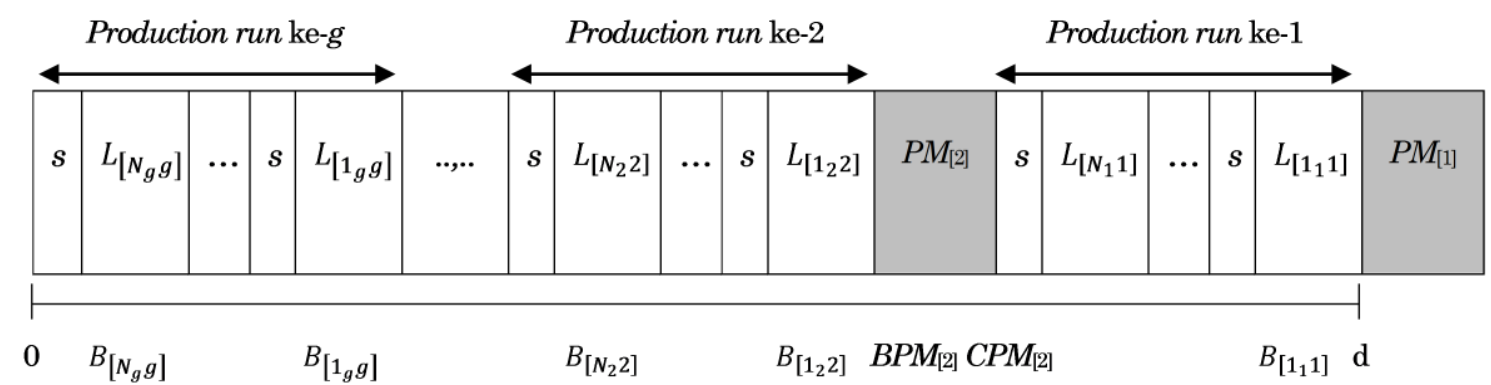

Gambar 2. Posisi batch dalam sistem manufaktur satu mesin dengan g production run

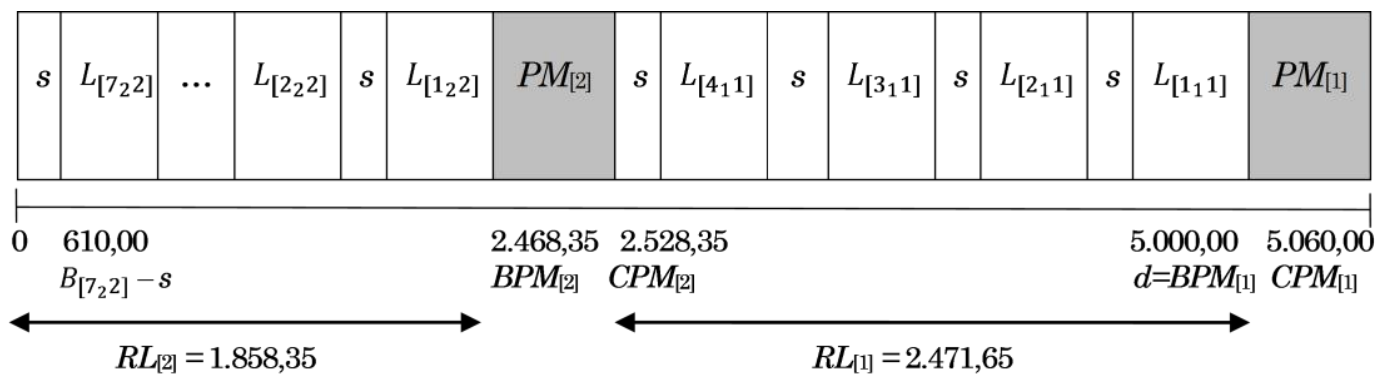

Gambar 3. Gantt-Chart solusi minimal studi kasus

$B_{\left[i_{k} k\right]}+\sum_{l=2}^{k}\left[\sum_{j_{l}=1}^{i_{l}}\left(s X_{\left[j_{l} l\right]}+t Q_{\left[j_{l} l\right]}+(k-1) t_{P M}\right)\right]-$

$s+\sum_{i_{1}=1}^{N_{1}}\left(s X_{\left[i_{1} 1\right]}+t Q_{\left[i_{1} 1\right]}\right)=d$,

$i_{k}=1,2, \ldots, N_{k}$ dan $k=2,3, \ldots, g$

$\sum_{i=1}^{N_{k}}\left(t Q_{[i k]}+s\right) \leq \sqrt[\beta-1]{\frac{\mu(1-A)}{A} \alpha^{\beta}}, k=1,2, \ldots, g$

$B P M[1]=d$,

$C P M[1]=d+t P M$,

$B P M[k]=B[1 k]+t Q_{[1 k]}, k=2,3, \ldots, g$,

$C P M[k]=B P M[k]+t P M, k=2,3, \ldots, g$,

$T=q t$

$x=\sqrt[\beta-1]{\frac{\mu(1-A)}{A} \alpha^{\beta}}$

$N s+\left(\left\lceil\frac{T}{x}\right\rceil-1\right) t_{P M}+t q \leq d$

$g=\lceil T / x\rceil$

$Q_{\left[i_{k} k\right]} \geq 0, i_{k}=1,2, \ldots, N_{k}, k=1,2, \ldots, g$

$Q_{\left[i_{k} k\right]} \leq X_{[i k]} q, i_{k}=1,2, \ldots, N_{k}, k=1,2, \ldots, g$

$N_{k} \geq 1, k=1,2, \ldots, g$ $\begin{aligned} X_{\left[i_{k} k\right]}= & \left\{\begin{array}{l}1, \text { jika } Q_{[i k]} \neq 0, \\ 0, \text { jika } Q_{[i k]}=0,\end{array}\right. \\ & i_{k}=1,2, \ldots, N_{k}, k=1,2, \ldots, g\end{aligned}$

Fungsi tujuan yang diminimumkan adalah total biaya yang terdiri dari biaya simpan, biaya perawatan preventif dan biaya setup, yang dirumuskan dengan Persamaan (6). Persamaan (7) menyatakan keseimbangan material di shop, yaitu jumlah part dalam semua batch harus sama dengan jumlah part yang akan dijadwal. Persamaan (8) dan (9) menyatakan waktu mulai semua batch masing-masing pada run pertama dan run selanjutnya. Setiap batch terjadwal harus sedekat mungkin dengan due date d. Persamaan (10) menyatakan waktu proses semua batch dalam setiap production run harus lebih kecil atau sama dengan $\sqrt[\beta-1]{\frac{\mu(1-A)}{A} \alpha^{\beta}}$, sebagaimana dirumuskan oleh Duarte dan Soares [22]. 
Persamaan (11) menyatakan suatu set kendala secara berturut-turut menyatakan waktu mulai PM [1] harus tepat saat waktu penyerahan $d$, waktu selesai PM [1] sama dengan $d$ ditambah lamanya waktu PM $t P M$, waktu mulai $\mathrm{PM}[\mathrm{k}]$ akan sama dengan waktu mulai batch pertama pada production run ke-k ditambah dengan waktu proses batch tersebut, serta waktu selesai PM[k] akan sama dengan waktu mulai $\mathrm{PM}[\mathrm{k}]$ ditambah dengan lamanya waktu PM $t P M, k=2,3, \ldots$, g. Asumsi yang digunakan adalah PM[1] terjadwal atau PM terakhir dilakukan setelah semua batch selesai diproses atau tepat saat due date untuk menjamin mesin dalam kondisi as good as new pada pengerjaan order berikutnya. Kendala (12) menyatakan total waktu proses semua part yang dijadwal. Kendala (13) menyatakan deklarasi $x$ sebagai panjang waktu maksimum antar dua PM berurutan dari Duarte dan Soares [22]. Kendala (14) menyatakan total waktu setup untuk total $N$ batch dan total waktu PM sepanjang planning horizon serta total waktu proses harus lebih kecil atau sama dengan due date d. Sehingga jumlah batch maksimum untuk $\mathrm{g}$ production run yang mungkin dapat dihitung dengan persamaan.

$$
N=\left[\frac{d-\left(\left[\frac{T}{x}\right]-1\right) t_{P M}-t q}{S}\right]
$$

Kendala (15) menyatakan jumlah run yang layak untuk suatu order ukuran $q$ part yang akan dijadwal. Kendala (16) menyatakan syarat kenonnegatifan variabel keputusan untuk ukuran batch terjadwal. Kendala (17) menyatakan kendala binary untuk batch terjadwal, dimana variabel binary $X_{\left[i_{k} k\right]}$ di set untuk setiap langkah dalam algoritma pencarian solusi. Kendala (18) menyatakan eksistensi jumlah batch dalam setiap run. Kendala (19) adalah kendala binary dimana setiap batch tak kosong akan memiliki nilai $X_{\left[i_{k} k\right]}=1$, dan setiap batch yang kosong akan memili nilai $X_{\left[i_{k} k\right]}=0$.

\section{Algoritma Pemecahan Model [SISS]}

Model ini termasuk kategori mixed integer non linear programming. Solusi analitik tidak dapat digunakan, karena teknik analitik mensyaratkan fungsi tujuan dan semua fungsi kendala adalah kontinu dan terdiferensialkan (Winston [22]). Dalam model terlihat ada beberapa kendala yang memuat variabel binary $X_{\left[i_{k} k\right]}$ dan $N k$ yang tidak kontinu. Untuk menyelesaikan Model [SISS] dirancang suatu algoritma optimisasi dengan melakukan relaksasi terhadap variabel binary $X_{\left[i_{k} k\right]}$, dan menetapkan nilai $X_{\left[i_{k} k\right]}=1$ atau $X_{\left[i_{k} k\right]}=0$, untuk $i_{k}=1,2, \ldots, N_{k}$, $k=1,2, \ldots, g$. Ambil $N k=\lfloor N\rfloor$, dengan $N$ dihitung dengan Persamaan (20) untuk $k=1,2, \ldots, g$, dan $g$ dihitung dengan Persamaan (15). Setiap relaksasi terhadap variabel binary $X_{\left[i_{k} k\right]}$ dan $N k$ maka model akan menjadi problem non linear programming biasa. Setiap problem non linear programming dalam algoritma diselesaikan dengan software Lingo. Software Lingo memberikan solusi local optimal untuk setiap iterasi dalam Algoritma [SISS]. Setiap iterasi dalam Algoritma [SISS] menghasilkan sebuah solusi feasible, dan kemudian Algoritma [SISS] melakukan pencarian solusi terbaik dari solusi-solusi feasible tersebut.

Algoritma [SISS] yang dikembangkan dimulai dengan pemeriksaan kelayakan problem terhadap model, dimana jumlah dari total waktu proses, jumlah waktu setup minimum dan jumlah waktu PM tidak akan melebihi waktu tenggat $d$. Kemudian hitung jumlah production run dan jumlah batch maksimum yang mungkin. Perhatikan production run pertama dari arah waktu tenggat $d$, naikkan jumlah batch pada production run ini sampai total biaya $T C$ meningkat atau jumlah batch maksimum tercapai. Lakukan ini untuk production run kedua dan seterusnya sampai g production run. Langkah akhir tulis solusi optimal dari problem sebagai nilai minimum $T C$ dan tulis semua variabel keputusan problem. Selengkapnya algoritma untuk Model [SISS] adalah sebagai berikut.

\section{Algoritma [SISS]}

L1 : Hitung $T=$ q.t. Lanjutkan ke L2.

L2 : Hitung panjang selang antar PM maksimum dengan Proposisi 1 dari Duarte dan Soares [22] atau dengan Persamaan (13), $x=$ $\sqrt[\beta-1]{\frac{\mu(1-A)}{A} \alpha^{\beta}}$. Lanjutkan ke L3

L3 : Problem layak jika dan hanya jika setiap production run memiliki satu batch atau dengan mengambil $N=\lceil T / x\rceil$, sehingga Persamaan (14) menjadi $\left\lceil\frac{T}{x}\right] s+\left(\left[\frac{T}{x}\right]-1\right) t_{P M}+t q \leq d$, jika terpenuhi problem layak, lanjutkan ke Langkah-4. Jika $\left[\frac{T}{x}\right] s+\left(\left[\frac{T}{x}\right]-1\right) t_{P M}+t q>d$, maka problem tidak layak, stop.

L4 : Hitung $g$ dengan persamaan (15), dan Set $N_{k}$ $=[N]$, dengan $N$ dihitung dengan Persamaan (20) untuk $k=1,2, \ldots$, g. Lanjutkan ke L5.

L5 : Substitusikan ke dalam model nilai-nilai $g$, $N_{k}, p, q, t, s, d, t_{P M}, x$ dan Set $X_{\left[i_{k} k\right]}=1$ untuk $i_{k}=1$ dan $k=1,2, \ldots, g, \operatorname{dan} X_{\left[i_{k}\right]}=0$ untuk $i_{k}, k$ yang lain. Lanjutkan ke L6.

L6 : Selesaikan Model [SISS] sebagaimana Langkah-5 untuk mendapatkan $T C$, tulis $T C_{\left[1_{1} 1\right]}=$ TC. Lanjutkan ke L7. 
L7 : Set $k=1$. Lanjutkan ke L8

L8 : Set $i_{k}=2$. Lanjutkan ke L9

L9 : Set $X_{\left[j_{l} l\right]}=1$ untuk $j_{l}=1,2, \ldots, i_{k}$ dan $l=1,2, \ldots$, $k$, dan Set $X_{\left[j_{l} l\right]}=0$ untuk $j_{l} l$ yang lain. Lanjutkan ke L10.

L10: Selesaikan Model [SISS] sebagaimana Langkah-9 untuk mendapatkan $T C$, tulis $T C_{\left[i_{k} k\right]}=$ TC. Lanjutkan ke L11

L11: Periksa apakah $T C_{\left[i_{k} k\right]}<T C_{\left[(i-1)_{k} k\right]}$ Jika ya, periksa apakah $i_{k}=N_{k}$, Jika ya, lanjutkan ke L12

Jika tidak, set $i_{k}=i_{k}+1$, kembali ke L9

Jika tidak, tulis $T C^{*}=T C_{\left[(i-1)_{k} k\right]}$ dan tulis semua variabel keputusan terkait $T C^{*}$. Lanjutkan ke L13.

L12: Tulis $T C^{*}=T C_{\left[i_{k} k\right]}$ dan tulis semua variabel keputusan terkait $T C^{*}$, lanjutkan ke L13.

L13: Periksa apakah $k=g$ Jika ya, lanjutkan ke L19

Jika tidak, lanjutkan ke L14

L14: Set $k=k+1$, lanjutkan ke L15

L15: Set ik $=2$, lanjutkan ke L16

L16: Set $X_{\left[j_{l} l\right]}=1$ untuk $j_{l}=1,2, \ldots, \quad i_{k}$ dan $l=$ $1,2, \ldots, k+1$ dan $X_{\left[j_{l}\right]}=0$ untuk $j_{l} l$ yang lain. Lanjutkan ke L17.

L17: Selesaikan Model [SISS] sebagaimana Langkah-16 untuk mendapatkan $T C$, tulis $T C_{\left[i_{(k+1)}(k+1)\right]}=T C$. Lanjutkan ke L18.

L18: Periksa apakah $T C_{\left[i_{(k+1)}(k+1)\right]}<T C^{*}$ Jika ya, Set $i_{k}=i_{k}+1$, kembali ke L16 Jika tidak, periksa apakah $k=g$ Jika ya. Lanjutkan ke L19.

Jika tidak. Set $k=k+1$, kembali ke L8

L19: Solusi minimal tercapai, hitung $R L[k]$ dan $N R[k]$ serta tulis semua nilai variabel keputusan

\section{Hasil dan Pembahasan}

\section{Studi Kasus}

Berikut ini disajikan suatu studi kasus dimana sebagian data berasal dari masalah nyata yang ditinjau dalam penelitian ini. Perusahaan $X$ adalah sebuah industri manufaktur yang memproduksi plate-1 sebagai bagian dari rotary bracket assembly untuk kapal. Proses pada mesin adalah frais single stage.

Misalkan sistem manufaktur ini harus memroses sejumlah part $q=200$ unit, waktu setup antar batch $s=30$ menit, waktu proses per part $t=20$ menit, panjang interval $P M$ konstan $t P M=60$ menit $=\frac{1}{\mu}$, parameter bentuk distribusi Weibull $\beta=1,692820$ dan parameter skala $a=2857,142857$, laju perbaikan konstan $\mu=\frac{1}{60}$, availabilitas target $A=98 \%$, waktu penyerahan seluruh part $d=5.000$, biaya simpan satuan finished part $c 1=$ US $\$ 0,20$ per unit per menit, biaya simpan satuan in process part $c 2=$ US\$ 0,10 per unit per menit, biaya satuan PM $c P M$ $=$ US $\$ 30$ per satu kali PM serta biaya satuan setup $c s=\mathrm{US} \$ 3$.

\section{Solusi}

L1 sampai L3 algoritma model memberikan $T=$ $4.000,4.000+2 \times 30+1 \times 60=4.120<5000, x=$ $2.471,65$, sehingga contoh ini layak untuk model.

L4 memberikan $g=2$ dan $N 1=N 2=32$.

L5 dan L6 memberikan $T C_{\left[1_{1} 1\right]}=101.625,50$.

L7 sampai L18 ditampilkan pada Tabel 1.

L19 menunjukkan solusi minimal contoh sebagaimana ditampilkan pada Tabel 2 .

\section{Perbandingan Solusi Studi Kasus dengan Praktek di Lapangan}

Bila Perusahaan $X$ menerapkan jadwal produksi dengan batch konstan dengan ukuran 20 part, dan perawatan mesin dilakukan hanya apabila terjadi kerusakan pada mesin (reactive maintenance). Apabila problem Contoh ini dijadwal dengan batch konstan, dimana 200 part akan dibagi menjadi 10 batch. Jika 10 batch ini dimasukkan ke dalam Algoritma [SISS] maka total biaya untuk ukuran batch konstan ini adalah US\$ 93.550,00 (lihat Tabel 3). Sementara dengan metoda yang dikembangkan total biaya adalah US $\$ 89.531,58$. Kerugian lain yang mungkin terjadi dalam praktek di perusahaan tersebut adalah kerusakan mesin terjadi pada saat kegiatan produksi sedang berlangsung. Tentu saja hal ini akan menimbulkan opportunity cost yang menjadi beban perusahaan. Metode yang dikembangkan akan memberikan efisiensi biaya paling sedikit $4,3 \%$.

\section{Analisis Sensitivitas}

Untuk melihat perilaku model terhadap perubahan parameter-parameter model dilakukan analisis sensitivitas sebagaimana dapat dilihat pada Tabel 4 . Tanda panah pada Tabel 4 menunjukkan perubahan nilai pada kolom yang berada di atas tanda panah.

Perubahan pada biaya satuan PM pada $q=200$ dan $d=5000$ memberikan kesimpulan bahwa urutan batch solusi terbaik algoritma [SISS] akan mengikuti metode SPT (short processing time), panjang 
production run pertama (dari arah due date) lebih besar dari production run kedua, perubahan biaya satuan PM pada model tidak mengubah urutan batch, dan waktu antar dua PM maksimum dimanfaatkan secara maksimal pada production run pertama. Gantt-Chart untuk solusi minimal Contoh dapat dilihat pada Gambar 3.

Perubahan pada biaya satuan PM pada $q=300, d=$ 10000) memberikan kesimpulan urutan batch selalu mengikuti metoda SPT (short processing time), panjang production run pertama (dari arah due date) lebih besar dari production run kedua, production run kedua lebih besar dari production run ketiga. Perubahan biaya satuan PM pada model tidak mengubah urutan batch, serta waktu antar dua PM maksimum dimanfaatkan secara maksimal pada production run pertama (dari arah due date).

Perubahan pada jumlah part yang dijadwal pada $d$ $=10000$ memberikan kesimpulan urutan batch selalu mengikuti SPT dan panjang production run pertama dari awal waktu produksi lebih kecil dari panjang production run berikutnya dan begitu seterusnya sampai waktu due date.

Perubahan pada biaya simpan finished part c1 pada $c 2=0,1, q=200$ dan $d=5000$ memberikan kesimpulan urutan batch mengikuti SPT, panjang production run pertama dari awal waktu produksi lebih kecil dari panjang production run berikutnya dan begitu seterusnya sampai waktu due date, dan dengan membesarnya $c 1$ maka diperkirakan jumlah batch akan mengecil dan total biaya TC meningkat dengan tajam.

Tabel 1. Iterasi algoritma pada L7 sampai L18

\begin{tabular}{ccr}
\hline $\begin{array}{c}\text { Jumlah batch } \\
\text { run-1 }\end{array}$ & $\begin{array}{c}\text { Jumlah batch } \\
\text { run-2 }\end{array}$ & \multicolumn{1}{c}{$T C_{\left[i_{k} k\right]}$} \\
\hline 2 & 1 & $95.709,48$ \\
3 & 1 & $94.270,54$ \\
4 & 1 & $94.104,33$ \\
5 & 1 & $94.442,70$ \\
& & $T C_{\left[5_{1} 1\right]}>T C_{\left[4_{1} 1\right]}$, \\
& & Set $k=2$ \\
4 & 2 & $90.953,76$ \\
4 & 3 & $90.058,40$ \\
4 & 4 & $89.715,60$ \\
4 & 5 & $89.581,22$ \\
4 & 6 & $89.537,55$ \\
4 & 7 & $89.531,58$ \\
4 & 8 & $89.538,72$ \\
& & $T C_{\left[8_{2} 2\right]}>T C_{\left[7_{2} 2\right]}$, \\
& & $k=2$, stop \\
\hline
\end{tabular}

Tabel 2. Solusi minimal studi kasus

\begin{tabular}{lccccc}
\hline$L_{\left[i_{k} k\right]}$ & $Q_{\left[i_{k} k\right]}$ & $B_{\left[i_{k} k\right]}$ & $B_{P M[k]}$ & $C_{P M[k]}$ & $T C^{*}$ \\
\hline$Q_{\left[1_{1} 1\right]}$ & 33,90 & $4.322,09$ & $B_{P M[1]}=$ & $C_{P M[1]}=$ & $89.531,58$ \\
& & & $5.000,00$ & $5.060,00$ & \\
$Q_{\left[2_{1} 1\right]}$ & 30,90 & $3.674,18$ & & & \\
$Q_{\left[3_{1} 1\right]}$ & 27,90 & $3.086,26$ & & & \\
$Q_{\left[4_{1} 1\right]}$ & 24,90 & $2.558,35$ & & & \\
$Q_{\left[1_{2} 2\right]}$ & 20,78 & $2.052,87$ & $B_{P M[2]}=$ & $C_{P M[2]}=$ & \\
& & & $2.468,35$ & $2.528,35$ & \\
$Q_{\left[2_{2} 2\right]}$ & 17,78 & $1.667,39$ & & & \\
$Q_{\left[3_{2} 2\right]}$ & 14,78 & $1.341,91$ & & & \\
$Q_{\left[4_{2} 2\right]}$ & 11,78 & $1.076,44$ & & \\
$Q_{\left[5_{2} 2\right]}$ & 8,78 & 870,96 & & \\
$Q_{\left[6_{2} 2\right]}$ & 5,78 & 725,48 & & \\
$Q_{\left[7_{2} 2\right]}$ & 2,78 & 640,00 & & & \\
\hline
\end{tabular}

Tabel 3. Solusi dengan penjadwalan produksi batch konstan

\begin{tabular}{lccccc}
\hline$L_{\left[i_{k} k\right]}$ & $Q_{\left[i_{k} k\right]}$ & $B_{\left[i_{k} k\right]}$ & $B_{P M[k]}$ & $C_{P M[k]}$ & $T C^{*}$ \\
\hline$Q_{\left[1_{1} 1\right]}$ & 20 & 4.600 & $B_{P M[1]}=$ & $C_{P M[1]}=$ & 93.550 \\
$Q_{\left[2_{1} 1\right]}$ & 20 & 4.170 & & & \\
$Q_{\left[3_{1} 1\right]}$ & 20 & 3.740 & & & \\
$Q_{\left[4_{1} 1\right]}$ & 20 & 3.310 & & & \\
$Q_{\left[5_{1} 1\right]}$ & 20 & 2.880 & & & \\
$Q_{\left[1_{2} 2\right]}$ & 20 & 2.390 & $B_{P M[2]}=$ & $C_{P M[2]}=$ & \\
$Q_{\left[2_{2} 2\right]}$ & 20 & 1.960 & & & \\
$Q_{\left[3_{2} 2\right]}$ & 20 & 1.530 & & & \\
$Q_{\left[4_{2} 2\right]}$ & 20 & 1.100 & & & \\
$Q_{\left[5_{2} 2\right]}$ & 20 & 670 & & & \\
\hline
\end{tabular}

Perubahan pada biaya simpan work in process part $c 2$ pada $c 1=0,2, q=200$ dan $d=5000$ ) memberikan kesimpulan urutan batch mengikuti SPT, dengan membesarnya $c 2$ panjang production run pertama dari awal waktu produksi lebih besar dari panjang production run berikutnya dan begitu seterusnya sampai waktu due date. Membesarnya c2 maka jumlah batch akan membesar.

Perubahan pada biaya setup antar batch $c S$ pada $c 1$ $=0,2 ; c 2=0,1 ; q=200$ dan $d=5000$ memberikan kesimpulan urutan batch mengikuti SPT, panjang interval production run membesar dari awal waktu produksi sampai waktu due date. Panjang production run pertama (dari arah due date) sama dengan panjang selang antar PM maksimum $x$, serta dengan membesarnya biaya satuan setup antar batch $c S$, maka diperkirakan jumlah batch optimal akan mengecil secara lambat. 


\section{Simpulan}

Model [SISS] mengintegrasikan penjadwalan batch dan penjadwalan preventive maintenance dengan kriteria minimisasi biaya simpan, biaya setup dan biaya perawatan preventif (preventive maintenancel PM). Model ini dapat menentukan jadwal produksi batch dan jadwal perawatan preventif (preventive maintenance/PM) secara bersamaan. Model ini mengasumsikan tidak ada part yang nonconforming selama suatu planning horizon.

Dari solusi Contoh dan analisis sensitivitas model terhadap perubahan parameter-parameter model dapat ditarik beberapa kesimpulan sebagai berikut. Urutan batch solusi terbaik algoritma [SISS] akan mengikuti metoda SPT (short processing time). Perubahan biaya satuan PM tidak mengubah urutan batch pada solusi terbaik. Panjang production run pertama dari awal waktu produksi lebih besar dari panjang production run kedua dan begitu seterusnya sampai waktu due date, kecuali dengan bertambahnya biaya simpan satuan work in process part c2. Apabila biaya simpan satuan work in process dinaikkan maka pola tersebut akan berlanjut sampai batas nilai biaya tertentu dan selanjutnya pola menjadi sebaliknya.

Penelitian ini dapat dikembangkan menjadi beberapa topik bahasan lebih lanjut, yaitu: Melepas asumsi bahwa tidak ada part yang non conforming selama berproduksi. Kasus sistem manufaktur multi item yang diproses pada satu mesin. Kasus sistem manufaktur flow shop.

\section{Daftar Pustaka}

1. Dobson, G., Karmarkar, U.S., and Rummel, J.L., Batching to Minimize Flow Times on One Machine, Management Science, 33, 1987, pp. 784799.

2. Dobson, G., Karmarkar, U.S., and Rummel, J.L., Batching to Minimize Flow Times on Heterogeneous Machines, Management Science, 35, 1989, pp. 607-613.

3. Halim, A.H., and Ohta, H., Batch-Scheduling Problems through Flow Shop with Both Receiving and Delivery Just in Time, International Journal of Production Research, 31, 1993, pp. 1943-1955.

4. Halim, A.H., and Ohta, H., Batch Scheduling Problems to Minimize Inventory Cost in the Shop with both Receiving and Delivery Just in Times, International Journal of Production Economics, 33, 1994, pp. 185-195.

5. Abboud, N.E., Jeber, and Noueihed, Economic Lot Sizing with the Consideration of Random Machine Unavailability Time, Journal of Computers and Operations Research, 27, 2000, pp. $335-351$.
6. Yeh, R.H., Ho, W.T., and Tseng, S.T., Optimal Production Run Length for Product Sold with Warranty, European Journal of Operation Research, 120, 2000, pp. 575-582.

7. Kim, C.H., Hong, Y., and Chang, S.Y., Optimal Production Run Length and Inspection Schedules in a Deteriorating Production Process, IIE Transaction, 33, 2001, pp. 421-426.

8. Herbon, A., Khmelnitsky, and Ben-Gal, I., Using a Pseudo-Stochastic Approach for Multiple-parts Scheduling on Unreliable Machine, IIE Transactions, 37, 2005, pp. 189-199.

9. Iravani, S.M.R., and Duenyas, I., Integrated Maintenance and Production Control of a Deteriorating Production System, IIE Transaction, 34, 2002, pp. 423-435.

10. Indrapriyatna, A.S., Suprayogi, Iskandar, B.P., dan Halim, A.H., Model Penjadwalan Batch pada Satu Mesin yang Mengalami Deteriorasi untuk Minimasi Total Biaya Simpan dan Biaya Kualitas, Jurnal Teknik Industri, 10(1), 2008, pp. 2637

11. Altendorfer, K., and Jodlbauer, H., An Analytical Model for Service Level and Tardiness in a Single Machine MTO Production System, International Journal of Production Research,49(7), 2011, pp. 1827-1850.

12. Lee, H.L., and Rosenblat, M.J., Simultaneous Determination of Production Cycle and Inspection Schedules in a Production System, Management Science, 33, 1987, pp. 1125-1136.

13. Wang, C.H., and Sheu, S.H., Simultaneous Determination of the Optimal Production Inventory and Product Inspection Policies for a Deteriorating Production System, Computers \& Operations Research, 28, 2001, pp. 1093-1110.

14.Tseng, S.T., Optimal Preventive Maintenance Policy for Deteriorating Production Systems, IIE Transactions, 28, 1996, pp. 687-694.

15. Ben-Daya, M. and Noman, S.A., Lot Sizing, Preventive Maintenance and Warranty Decisions for Imperfect Production Systems, Journal of Quality in Maintenance Engineering, 12(1), 2006, pp. 68-80.

16. Lin, L.C., and Hou, K.L., EMQ Model with Maintenance Actions for Deteriorating Production System, Information and Management Sciences, 16(1), 2005, pp. 53-65.

17. Chelbi, A., Rezg, N., and Radhoui, M., Simultaneous Determination of Production Lot Size and Preventive Maintenance Schedule for Unreliable Production System, Journal of Quality in Maintenance Engineering, 14(2), 2008, pp. 161-176.

18. Makhdoum, M.A.A., Integrated Production, Quality and Maintenance Models under Various Preventive Maintenance Policies, Thesis, Graduate Studies, King Fahd University of Petroleum and Minerals, Saudi Arabia, 1996. 
19. El-Ferik, S., and Ben-Daya, M., Integrated Production Maintenance Model under Imperfect Age-Based Maintenance Policy and Non-Negligible Maintenace Times, Asia-Pacific Journal of Operational Research, 27(4), 2010, pp. 539-558.

20. Fitouhi, M.C., and Nourelfath, M., Integrating Noncyclical Preventive Maintenance Scheduling and Production Planning for a Single Machine, International Journal of Production Economic, 136(2), 2012, pp. 344-351.
21. Suliman, S.M.A., and Jawad, S.H., Optimization of Preventive Maintenance Schedule and Production Lot Size, International Journal of Production Economics, 137(1), 2012, pp. 19-28.

22. Duarte, J.C., and Soares, C.G., Optimisation of Preventive Maintenance Plan of a Series Components System with Weibull Hazard Function, Reliability Theory and Applications, 4, 2007, pp. 33-39, December - Special Issue.

23. Winston, W. L., Operations Research, Application and Algorithm, $3^{\text {rd }}$ edition, Duxbury Press, USA, 1994. 